\title{
MEKANISME PENINGKATAN BADAN USAHA PERSEKUTUAN KOMANDITER (CV) MENJADI BADAN HUKUM PERSEROAN TERBATAS (PT)
}

\author{
Yayah Wariah $^{1}$
}

\begin{abstract}
ABSTRAK
Dunia bisnis selalu penuh dengan perkembangan yang memerlukan respon dan pengambilan keputusan yang segera, sehingga dapat mengantisipasi perubahan itu. Salah satu bentuk perubahan itu adalah apabila suatu bisnis yang sebelumnya berbentuk badan usaha Perseroan Komanditer (CV) akan dirubah statusnya menjadi badan hukum Perseroan Terbatas (PT). Perbedaan prinsipil antara Perseroan Komanditer atau dikenal dengan sebutan CV (Commanditaire vennootschap) dengan Perseroan Terbatas (PT) terdapat pada status badan hukumnya, karena CV merupakan persekutuan yang tidak berbadan hukum dan tanggungjawab dari para sekutu pengurus hanya sampai kepada harta pribadinya. Sedangkan Perseroan Terbatas (PT) merupakan perseoran berbadan hukum dan tanggungjawabnya terbatas. Adapun Tujuan penelitian ini adalah untuk meneliti dan menganalisis mekanisme perubahan Persekutuan Komanditer (CV) Menjadi Badan Hukum Perseroan Terbatas (PT).Untuk menganalisis Tanggung Jawab Sekutu Komplementer Terhadap Perseroan Terbatas (PT) Yang Didirikan.

Metode penelitian yang digunakan adalah penelitian hukum normatif yang bersifat deskriptif analisis, pengumpulan data dilakukan dengan menggunakan data primer dan data sekunder berupa bahan hukum primer, sekunder dan tertier sebagai data utama. Setelah data sekunder dan primer terkumpul, kemudian diadakan analisis secara kualitatif

Berdasarkan hasil analisis data disimpulkan bahwa Prosedur pengalihan asset dari CV kepada PT harus sesuai dengan ketentuan peraturan perundang-undangan yang berlaku di bidang PT. Langkah pertama pengalihan asset tersebut adalah dengan mengadakan Rapat Umum Pemegang Saham (RUPS) untuk meminta persetujuan para persero dalam pengalihan asset dari CV kepada PT sebagaimana diketahui dalam PT, RUPS adalah organ perseroan yang mempunyai wewenang yang tidak diberikan kepada direksi atau dewan komisaris dalam batas yang ditentukan dalam Undang-Undang PT Nomor 40 Tahun 2007 dan/atau anggaran dasar PT. Terdapatnya dua jenis sekutu dalam Persekutuan Komanditer, yaitu sekutu komplementer dan sekutu komanditer mengakibatkan terdapatnya dua jenis tanggung jawab pula, yaitu tanggung jawab tidak terbatas (unlimited liability) dan tanggung jawab terbatas (limited liability). Pertanggunggjawaban sekutu komplementer apabila melakukan perbuatan hukum sebagaimana dimaksud dalam Pasal 12 dan Pasal 13 UUPT, maka terjadi peralihan hak dan kewajiban dari sekutu komplementer tersebut ke dalam perseroan dan perbuatan hukum yang dilakukan oleh sekutu komplementer tersebut mengikat perseroan.
\end{abstract}

\section{Kata Kunci: Badan Usaha,Persekutuan Komanditer,Perseroan Terbatas}

\footnotetext{
${ }^{1}$ Staff kantor Notaris ....., email tehyayah79@gmail.com
} 


\section{A. Latar Belakang Masalah}

Persekutuan merupakan bentuk badan usaha yang paling sederhana untuk mencapai suatu keuntungan bersama. Hal ini disebabkan pendirian persekutuan tidak diharuskan adanya akta otentik maupun pengesahan dari instansi yang berwenang. ${ }^{2}$ Namun sebagian besar pendiri dari CV seringkali menggunakan akta otentik untuk mendirikan dan menjalakan usahanya tersebut. Hal ini disebabkan CV memiliki karakteristik yang berbeda dengan perusahaan persekutuan lainnya. Perbedaan yang paling mencolok dari CV terletak pada adanya sekutu komanditer dan sekutu komplementer yang dimana sekutu komplementer berwenang sebagai sekutu yang mengurus sedangkan sekutu komanditer berwenang sebagai sekutu yang yang memasukkan uang atau benda ke dalam persekutuan sebagai pemasukan (inbreng) dan berhak atas keuntungan dari persekutuan tersebut ${ }^{3}$. Sehingga segala bentuk kewenangan para sekutu yang telah disepakati tersebut, tidak dapat diubah dengan serta merta.

Sekutu komanditer dilarang melakukan pengurusan meskipun dengan surat kuasa. Ia hanya boleh mengawasi pengurusan jika memang ditentukan demikian di dalam Anggaran Dasar persekutuan. Bila ketentuan ini dilanggar, Pasal 21 KUHD $^{4}$ memberi sanksi dimana sekutu komplementer bertanggung jawab secara pribadi untuk keseluruhan. Dalam CV hanya sekutu komplementer (Direksi) yang

2 Kitab Undang-undang Hukum Dagang, Staatsblad 1847-23, Pasal 22 KUHD

3 Ridwan Khairandy, Pokok-PokokHukum Dagang Indonesia, Pustaka Pelajar, Jakarta. 2013, hlm. 26

${ }^{4}$ Pasal 21 KUHD yang menyatakan : "Persero komanditer yang melanggar ketentuan-ketentuan alinea pertama atau alinea kedua dari pasal yang lain, bertanggung jawab secara tanggung renteng untuk seluruhnya terhadap semua utang dan perikatan perseroan itu. (KUHD 18.)". boleh mengadakan hubungan terhadap pihak ketiga. Sedangkan status hukum seorang sekutu komanditer dapat disamakan dengan seorang yang meminjamkan atau menanamkan modal pada suatu perusahaan dan diharapkan dari penanaman modal itu adalah hasil keuntungan dari modal yang dipinjamkan atau ditanamkan tersebut.

Adanya risiko yang dapat melibatkan harta pribadi dari sekutu komplementer tersebut disebabkan CV sekali pun didirikan dengan adanya akta otentik tetap bukan merupakan badan hukum. Hal ini disebabkan ketentuan dalam KUHD tidak mengharuskan pendirian $\mathrm{CV}$ mendapatkan pengesahan badan hukum dari instansi yang berwenang. Segala kewenangan CV tetap merupakan kewenangan para sekutu komplementer, bukanlah kewenangan perusahaan/ persekutuan. Sehingga hal ini menuntut para sekutu meningkatkan statusnya menjadi badan hukum agar dapat melindungi harta pribadinya.

Usaha untuk melakukan perubahan terhadap $\mathrm{CV}$ menjadi $\mathrm{PT}^{5}$ tentu memiliki permasalahan. Hal ini disebabkan CV telah berdiri terlebih dahulu dan melakukan perbuatan hukum yang dapat berupa Perjanjian Kredit, Penjaminan, maupun transaksi keuangan lainnya dengan pihak ketiga. Selain itu, permasalahan lain yang menjadi kendala dalam perubahan $\mathrm{CV}$ menjadi PT juga terdapat pada dasar hukum yang sangat terbatas dan hingga kini tidak ada dasar hukum yang spesifik yang dapat merubah CV menjadi PT. Keperluan atas dasar hukum yang spesifik tersebut juga menyebabkan adanya ketidakjelasan terkait dengan prosedur serta mekanisme yang

5 Irma Devina, Peningkatan Bentuk Perusahaan Dari CV Menjadi PT, https:// irmadevita. com/2011/ peningkatan-bentuk-perusahaan-dari-cvmenjadi-pt/diakses tanggal 11/10/2018 
dapat digunakan untuk melakukan perubahan CV menjadi PT. Untuk itu, penulis hendak mengkaji lebih dalam bagaimana proses pendirian PT yang berasal dari CV dapat dilakukan dengan menjamin kepastian hukum yang setinggi-tingginya. Sehingga dengan adanya kepastian hukum, maka setelah PT berdiri selain menjalankan prosedur hukum yang tepat juga dapat mengambil alih segala perbuatan hukum yang telah dilakukan oleh $\mathrm{CV}$ tersebut menjadi tanggung jawab PT bukan tanggung jawab pribadi dari para sekutu komplementer.

Berdasarkan dari latar belakang tersebut, maka penulis tertarik untuk melakukan penelitian lebih lanjut yang akan dituangkan dalam bentuk penelitian dengan judul " Mekanisme Peningkatan Badan Usaha Persekutuan Komanditer (CV) Menjadi Badan Hukum Perseroan Terbatas (PT)".

\section{B. Rumusan Masalah}

Berdasarkan uraian latar belakang masalah di atas, maka yang menjadi permasalahan adalah:

1. Bagaimanakah Mekanisme Perubahan Persekutuan Komanditer (CV) Menjadi Badan Hukum Perseroan Terbatas (PT)?

2. Bagaimana Tanggung Jawab Sekutu Komplementer Terhadap Perseroan Terbatas (PT) Yang Didirikan

\section{Tujuan Penelitian}

Sesuai dengan permasalahan di atas, maka tujuan penelitian ini adalah:

1. Untuk meneliti dan menganalisis mekanisme perubahan Persekutuan Komanditer (CV) Menjadi Badan Hukum Perseroan Terbatas (PT)?

2. Untuk menganalisis Tanggung Jawab Sekutu Komplementer Terhadap Perseroan Terbatas (PT) Yang Didirikan?

\section{Kerangka Pemikiran}

Menurut M. Solly Lubis yang menyatakan konsep teori merupakan "Kerangka pemikiran atau butir-butir pendapat, mengenai suatu kasus ataupun permasalahan (problem) yang bagi si pembaca menjadi bahan perbandingan, pegangan teori, yang mungkin ia setuju ataupun tidak disetujuinya merupakan masukan eksternal bagi peneliti". 6

Kerangka teori dalam penelitian hukum sangat diperlukan untuk membuat jelas nilai-nilai oleh postulat-postulat hukum sampai kepada landasan filosofisnya yang tertinggi. ${ }^{7}$ Teori hukum sendiri boleh disebut sebagai kelanjutan dari mempelajari hukum positif, setidak-tidaknya dalam urutan yang demikian itulah kita merekonstruksikan kehadiran teori hukum secara jelas. ${ }^{8}$

Sebagai kerangka teori yang akan dibahas dalam tulisan ini dengan aliran hukum positif yang analistis dari Jhon Austin, Jhon Austin dengan analytical legal positivism-nya menjadi penganut utama aliran positivisme yuridis. Austin bertolak dari kenyataan bahwa terdapat suatu kekuasaan yang memberikan perintahperintah dan ada orang yang pada umumnya mentaati perintah-perintah itu. Tidak penting mengapa orang mentaati perintah-perintah itu. Bahwa mereka mentaati karena takut, atau karena rasa hormat, atau karena merasa dipaksa, sama saja. Yang penting,faktanya adalah ada orang yang mentaati aturan itu. Kalau tidak, dijatuhkan sanksi, maka untuk dapat disebut hukum menurut Austin diperlukan adanya unsur-unsur yang berikut:
a. Adanya seorang penguasa (souvereighnity),
b. Suatu perintah (command),
c. Kewajiban untuk mentaati (duty),

${ }^{6}$ M. Solly Lubis, Filsafat Ilmu dan Penelitian, CV. Mandar Maju, Bandung, 1994,hlm. 80

7 Satjipto Rahardjo, llmu Hukum, P.T. Citra Aditya Bakti, Bandung, 1991, hlm. 254.

${ }^{8}$ Ibid, hlm. 253 
d. Sanksi bagi mereka yang tidak taat (sanction). ${ }^{9}$

Perbedaan prinsipil antara Perseroan Komanditer atau dikenal dengan sebutan CV (Commanditaire vennootschap) dengan Perseroan Terbatas (PT) terdapat pada status badan hukumnya, karena CV merupakan persekutuan yang tidak berbadan hukum dan tanggungjawab dari para sekutu pengurus hanya sampai kepada harta pribadinya. Sedangkan Perseroan Terbatas (PT) merupakan perseoran berbadan hukum dan tanggungjawabnya terbatas. Perubahan CV menjadi Perseroan Terbatas (PT) dilakukan melalui notaris tanpa harus membubarkan CV terlebih dahulu. Perubahan CV menjadi Perseroan Terbatas (PT) berarti akan mengubah status perusahaan yang awalnya tidak berbadan hukum menjadi badan hukum. Untuk itu terdapat hal-hal yang perlu diperhatikan dan disesuaikan agar dapat memperoleh status badan hukum sebagaimana yang diatur dalam UndangUndang No. 40 Tahun 2007 tentang Perseroan Terbatas (UUPT).

Adapun hal-hal yang perlu disesuaikan berdasarkan ketentuan Undang-Undang No. 40 Tahun 2007 tentang Perseroan Terbatas adalah sebagai berikut :

a. Menyelesaikan terlebih dahulu perikatan yang telah terjadi antara para pengurus $\mathrm{CV}$ dengan pihak ketiga.

b. Menyesuaikan Anggaran Dasar CV. Hal ini dilakukan karena pada Anggaran Dasar CV tidak ada ketentuan mengenai Modal Dasar, Modal Ditempatkan, dan Modal Disetor. Sedangkan untuk menjadi Perseroan Terbatas harus memenuhi ketentuan mengenai Modal Dasar Perseroan Terbatas, yakni minimal Rp. 50.000.000 (Berdasarkan Pasal

9 Satjipto Rahardjo, Teori Hukum, Genta Publishing, Yogyakarta, 2010, hlm 120.
32 ayat (1) UUPT), dan $25 \%$ dari modal dasar harus ditempatkan dan disetor penuh (Berdasarkan Pasal 33 ayat (1) UUPT). Dengan demikian, Anggaran Dasar CV harus disesuaikan dengan ketentuan tersebut.

c. Membuat Akta pendirian (akta notaris) yang memuat Anggaran Dasar dan keterangan lain berkaitan dengan pendirian Perseroan Terbatas (Berdasarkan Pasal 7 ayat (1) jo. Pasal 8 ayat (1) UUPT).

d. Para pendiri bersama-sama mengajukan permohonan pengesahan badan hukum melalui jasa teknologi informasi sistem administrasi badan hukum secara elektronik kepada Menteri Hukum dan HAM (Berdasarkan Pasal 1 angka 16 jo. Pasal 9 ayat (1) UUPT.

e. Setelah dilakukan pengesahan, Menteri akan melakukan pendaftaran Perseroan Terbatas (Berdasarkan Pasal 29 ayat (1) UUPT).

f. Pengumuman di Tambahan Berita Negara RI oleh Menteri (Berdasarkan Pasal 30 ayat (1) UUPT). ${ }^{10}$

Dan perubahan itu dapat dilakukan melalui cara berikut ini :

a. Seluruh sekutu harus setuju akan keinginan itu dan melakukan rapat dengan atau tanpa kehadiran notaris yang kemudian akan menghasilkan putusan perubahan itu dalam bentuk berita acara.

b. Seluruh aset bergerak maupun tidak bergerak Perseroan Komanditer (CV) harus di taksasi (penilaian

10 NOTARIS SIDOARJO, Perubahan $C V$ Menjadi PT, http://notaris-sidoarjo. blogspot. com/2012/11/perubahan-cv-menjadi-pt_26.html diakses tanggal 19/09/2018 
dalam jumlah rupiah) sebaiknya dilakukan oleh independen auditor.

c. Dari total aset lalu ditentukan berapa besar bagian masing-masing dan apakah seluruhnya atau sebagian akan di inb reng (dimasukkan) ke dalam Perseroan Terbatas sebagai modal yang akan disetor oleh masing-masing pendiri Perseroan Terbatas (PT).

d. Datang ke Notaris untuk membuat Akta Pendirian Perseroan Terbatas (PT) dengan sudah menentukan nama, kedudukan, maksud dan tujuan, pemegang saham, susunan pengurus dan modal Perseroan Terbatas (PT).

e. Setelah proses pendirian Perseroan Terbatas (PT) tentu saja harus mengubah seluruh administrasi dan keuangan yang ada karena telah beralih status dari badan usaha menjadi badan hukum.

\section{E. Metode Penelitian}

Metode adalah proses, prinsip-prinsip dan tata cara memecahkan suatu masalah, sedangkan penelitian adalah pemeriksaan secara hati-hati, tekun dan tuntas terhadap suatu gejala untuk menambah pengetahuan manusia, maka metode penelitian dapat diartikan sebagai proses, prinsip-prinsip atau tata cara untuk memecahkan masalah yang dihadapi dalam melakukan penelitian ${ }^{11}$. Dengan demikian penelitian yang dilaksanakan tidak lain untuk memperoleh hasil uji hipotesis ilmiahnya, namun untuk mencapai kebenaran ilmiah tersebut ada 2 (dua) pola pikir menurut sejarahnya, yaitu berfikir secara rasional dan berfikir secara normatif. Oleh karena itu untuk menemukan

11 Soerjono Soekanto dan Sri Mamudji, Pengantar Penelitian Hukum Normatif, UI Press, Jakarta, 2006, hlm. 6 metode ilmiah, maka digabungkanlah metode pendekatan rasional dan pendekatan normatif.

\section{Metode Pendekatan}

Metode Pendekatan yang digunakan dalam penelitian ini adalah yuridis normatif. Johnny Ibrahim mengatakan nilai ilmiah suatu pembahasan dan pemecahan masalah terhadap legal issue yang diteliti sangat tergantung kepada cara pendekatan yang digunakan. Jika cara pendekatan tidak tepat, maka bobot penelitian tidak akurat dan kebenarannya pun dapat digugurkan. ${ }^{12}$ Penggunaan penelitian yuridis normatif ${ }^{13}$ dilakukan karena kajian dalam penelitian ini adalah kajian ilmu hukum oleh karena itu harus dikaji dari aspek hukumnya. Penelitian yuridis normatif disebut juga penelitian hukum kepustakaan. ${ }^{14}$ Arief Sidharta mengatakan penelitian hukum normatif adalah jenis penelitian yang lazim dilakukan dalam kegiatan pengembangan ilmu hukum yang di barat biasa juga disebut dogmatika hukum. Mochtar Kusumaatmadja dan Koesnoe menyebutnya ilmu hukum positif. ${ }^{15}$ Johnny Ibrahim menyebut penelitian hukum normatif suatu prosedur penelitian ilmiah untuk menemukan kebenaran berdasarkan logika keilmuan hukum dari sisi normatifnya. ${ }^{16}$

Penelitian ini dikategorikan sebagai penelitian hukum normatif (legal

12 Johnny Ibrahim, Teori dan Metodologi Penelitian Hukum Normatif, Bayumedia Publishing, Cetakan Keempat, Malang, 2011,hlm. 299.

13 Ronny Hanitijo Soemitro, Metodologi Penelitian Hukum dan Jurimetri, Semarang, Ghalia Indonesia, 1988, hlm. 11.

${ }^{14}$ Ibid.

15 Bernard Arief Sidharta, "Penelitian Hukum Normatif: Analisis Penelitian Filosofikal dan Dogmatikal", dalam Sulistyowati Irianto dan Shidarta (Editor), Metode Penelitian Hukum Konstelasi dan Refleksi, Cetakan kedua, Yayasan Pustaka Obor Indonesia, Jakarta, 2011, hlm. 142.

16 Johnny Ibrahim, Op.Cit.,h. 57. 
research), ${ }^{17}$ yaitu penelitian yang mengkaji asas-asas dan kaidah-kaidah hukum. Digunakannya penelitian hukum normatif karena, permasalahan pokok tesis ini mengenai peningkatan badan usaha dari $\mathrm{CV}$ menjadi badan hukum PT. Di samping itu, penelitian ini menggunakan pendekatan perundang-undangan (statute approach) yaitu dilakukan dengan menelaah semua undang-undang dan regulasi yang berkaitan dengan peningkatan badan usaha dari $\mathrm{CV}$ menjadi badan hukum $\mathrm{PT}^{18}$.

\section{Spesifikasi Penelitian}

Penelitian ini bersifat deskriptif, maksudnya karena peneliti berusaha mengetahui dan memaparkan informasi dan data secara faktual dengan cara sistematis dan akurat mengenai peningkatan badan usaha dari CV menjadi badan hukum PT. Bersifat analisis karena peneliti akan melakukan analisa terhadap berbagai aspek hukum, baik dari segi peraturan maupun dari segi pelaksanaannya, guna mengetahui bagaimana pemerintah melakukan regulasi peningkatan badan usaha dari CV menjadi badan hukum PT.

\section{Metode Pengumpulan Data}

Metode yang dipergunakan untuk pengambilan data yaitu menggunakan data primer dan data sekunder yang terdiri dari :

17 Ronny Hanitijo Soemitro, Metodologi Penelitian Hukum dan Jurimetri, Ghalia Indonesia, Jakarta, 1990,hlm. 11-12.

18 Soerjono Soekanto dan Sri Mamudji, Op.Cit., hlm. 14. Lihat juga Peter Mahmud Marzuki, 2010, Penelitian Hukum, Kencana, Jakarta, hlm. 93. Bahder Johan Nasution, Metode Penelitian Ilmu Hukum, Mandar Maju, Bandung, 2008, hlm. 86. Zainuddin Ali, Metode Penelitian Hukum, Sinar Grafika, Jakarta, 2009, hlm. 25-30. Abu Yasid, Aspek-aspek Penelitian Hukum; Hukum Islam Hukum Barat, Pustaka Pelajar, Yogyakarta, 2010,hlm. 72-85. a. Studi kepustakaan yaitu dengan mempelajari literatur-literatur yang berhubungan dengan objek penelitian.

b. Wawancara (interview) yaitu mengumpulkan data dengan cara tanya jawab dengan para pihak yang terkait dengan objek penelitian. Sedangkan tipe wawancara yang dipergunakan adalah wawancara tidak terpimpin (non directive interview) artinya seluruh wawancara tidak didasarkan pada satu sistem atau daftar pertanyaan yang telah disusun terlebih dahulu.

\section{Teknik Analisis Data}

Setelah data sekunder dan primer terkumpul, kemudian diadakan analisis secara kualitatif yaitu menganalisis data berupa uraian-uraian yang sistematis tanpa mempergunakan bagan-bagan dan rumus statistik. Namun sebelum analisis dilakukan, terlebih dahulu diadakan pemeriksaan dan evaluasi terhadap semua data yang ada untuk mengetahui validitasnya. Bambang Waluyo mengatakan bahwa terhadap data yang sudah terkumpul dapat dilakukan analisis kualitatif apabila: ${ }^{19}$

a. Data yang terkumpul tidak berupa angka-angka yang dapat dilakukan pengukurannya;

b. Data tersebut sukar diukur dengan angka;

c. Hubungan antara variable tidak jelas;

d. Sampel lebih bersifat non probabilitas;

e. Pengumpulan data menggunakan pedoman wawancara dan pengamatan;

f. Penggunaan-penggunaan teori kurang diperlukan.

19 Bambang Waluyo, Penelitian Hukum Dalam Praktek, Sinar Grafika, Jakarta, 1996, hlm. 77-78. 
Analisis hasil yang digunakan adalah dengan mengidentifikasikan pengertianpengertian pokok atau dasar dalam hukum yaitu masyarakat hukum, subyek hukum, hak dan kewajiban, peristiwa hukum, hubungan hukum dan obyek hukum. Setelah pengertian pokok atau dasar teridentifikasi, dilanjutkan gambaran secara kualitatif terhadap peningkatan badan usaha dari $\mathrm{CV}$ menjadi badan hukum PT.

Selanjutnya dilakukan analisis mengenai taraf sinkronisasi peraturan perundang-undangan yang berkaitan peningkatan badan usaha dari $\mathrm{CV}$ menjadi badan hukum PT. Dengan demikian dapat dilihat sistematisasi dan analisis hukum yang digunakan dengan mengidentifikasikan materi muatan peraturan perundangundangan sesuai dengan kewenangan dari setiap produk hukum yang tertera pada hirarki peraturan perundang-undangan. Sehingga dapat diperoleh kesimpulan dari penelitian yang dilakukan, yang merupakan jawaban atas permasalahan yang diteliti dan telah diuji secara ilmiah, sehingga melahirkan suatu pembenaran.

\section{F. Hasil Penelitian dan Pembahasan}

\section{Mekanisme Perubahan Persekutuan Komanditer (CV) Menjadi Badan Hukum Perseroan Terbatas (PT) \\ Perubahan status badan usaha CV} menjadi badan hukum PT adalah merupakan suatu fakta hukum. Fakta hukum adalah kejadian-kejadian, perbuatan/tindakan, atau keadaan yang menimbulkan, beralihnya, berubahnya atau berakhirnya suatu hak. Singkatnya fakta hukum adalah fakta yang menimbulkan akibat hukum. ${ }^{20}$ Dalam Pasal 1618 KUHPerdata dikatakan bahwa tiap

20 Herlien Budiono, Ajaran Umum Hukum Perjanjian dan Penerpannya di Bidang Kenotariatan, PT. Citra Aditya Bakti, Bandung, 2009,hlm. 3 peserta harus memasukkan sesuatu ke dalam persekutuan. Hal yang dimaksudkan disini adalah "pemasukan" (inbreng). Yang dimaksud dengan "pemasukan" (inbreng) bisa berwujud barang, uang atau tenaga, baik tenaga badaniah maupun tenaga kejiwaan (pikiran). Adapun hasil dari adanya pemasukan itu tidak hanya keuntungan saja, tetapi mungkin pula "kemanfaatan", Pasal 1618 KUHPerdata dikatakan bahwa tiap peserta harus memasukkan sesuatu ke dalam persekutuan. Hal yang dimaksudkan disini adalah "pemasukan" (inbreng). Yang dimaksud dengan "pemasukan" (inbreng) bisa berwujud barang, uang atau tenaga, baik tenaga badaniah maupun tenaga kejiwaan (pikiran). Adapun hasil dari adanya pemasukan itu tidak hanya keuntungan saja, tetapi mungkin pula "kemanfaatan".

Prosedur pengalihan asset dari CV kepada PT harus sesuai dengan ketentuan peraturan perundang-undangan yang berlaku di bidang PT. Langkah pertama pengalihan asset tersebut adalah dengan mengadakan Rapat Umum Pemegang Saham (RUPS) untuk meminta persetujuan para persero dalam pengalihan asset dari CV kepada PT sebagaimana diketahui dalam PT, RUPS adalah organ perseroan yang mempunyai wewenang yang tidak diberikan kepada direksi atau dewan komisaris dalam batas yang ditentukan dalam Undang-Undang PT Nomor 40 Tahun 2007 dan/atau anggaran dasar PT. ${ }^{21}$

Sesuai dengan namanya RUPS merupakan termin dimana para pemegang saham untuk membahas segala sesuatu yang berhubungan dengan PT. RUPS merupakan salah satu organ dari perseroan disamping direksi dan komisaris. Bila dalam UndangUndang Nomor 1 Tahun 1995, RUPS adalah organ perseroan yang memegang kekuasaan

21 Binoto Nadapdap, Hukum Perseroan Terbatas, Permata Aksara, Jakarta, 2012,hlm. 111 
tertinggi dalam perseroan dan memegang segala wewenang yang tidak diserahkan kepada direksi atau komisaris.

Ketentuan mengenai RUPS sebagai pemegang kekuasaan tertinggi dalam sebuah perseroan terbatas telah dihilangkan didalam Undang-Undang Nomor 40 Tahun 2007 kedudukan RUPS sebagai salah satu organ perseroan adalah sama dengan organ perseroan adalah sederajat yang membedakan antara ketiga organ perseroan tersebut adalah soal pembagian wewenang menurut Undang-Undang 40 Tahun 2007, RUPS memiliki wewenang yang tidak dimiliki oleh direksi dan/atau komisaris. Dengan kata lain RUPS mempunyai wewenang yang telah diberikan kepada Direksi atau Dewan Direksi atau Dewan Komisaris dalam batas yang ditentukan dalam Undang-Undang Nomor 40 Tahun 2007 tentang PT, dan/atau anggaran dasar. Hal ini sesuai dengan Pasal 75 ayat (1) Undang-Undang Nomor 40 Tahun 2007. Pasal 75 ayat (2) Undang-Undang Nomor 40 Tahun 2007 berbunyi, "Dalam forum RUPS, pemegang saham berhak memperoleh keterangan yang berkaitan dengan perseroan dari Direksi dan/atau Dewan Komisaris, sepanjang berhubungan dengan mata acara rapat dan tidak bertentangan dengan kepentingan perseroan". Pasal 75 ayat (3) Undang-Undang Nomor 40 Tahun 2007 berbunyi, "RUPS dalam mata acara lain-lain tidak berhak mengambil keputusan, kecuali semua pemegang saham hadir dan/atau diwakili dalam RUPS dan menyetujui penambahan mata acara rapat”.

Perbedaan prinsipil antara Perseroan Komanditer atau dikenal dengan sebutan CV (Commanditaire vennootschap) dengan Perseroan Terbatas (PT) terdapat pada status badan hukumnya, karena CV merupakan persekutuan yang tidak berbadan hukum dan tanggungjawab dari para sekutu pengurus hanya sampai kepada harta pribadinya. Sedangkan Perseroan Terbatas
(PT) merupakan perseoran berbadan hukum dan tanggungjawabnya terbatas. Mekanisme Perubahan CV menjadi Perseroan Terbatas (PT) dilakukan melalui notaris tanpa harus membubarkan CV terlebih dahulu. Perubahan CV menjadi Perseroan Terbatas (PT) berarti akan mengubah status perusahaan yang awalnya tidak berbadan hukum menjadi badan hukum. Untuk itu terdapat hal-hal yang perlu diperhatikan dan disesuaikan agar dapat memperoleh status badan hukum sebagaimana yang diatur dalam Undang-Undang No. 40 Tahun 2007 tentang Perseroan Terbatas (UUPT). Adapun hal-hal yang perlu disesuaikan berdasarkan ketentuan Undang-Undang No. 40 Tahun 2007 tentang Perseroan Terbatas adalah sebagai berikut ${ }^{22}$ :

a. Menyelesaikan terlebih dahulu perikatan yang telah terjadi antara para pengurus $\mathrm{CV}$ dengan pihak ketiga.

b. Menyesuaikan Anggaran Dasar CV. Hal ini dilakukan karena pada Anggaran Dasar CV tidak ada ketentuan mengenai Modal Dasar, Modal Ditempatkan, dan Modal Disetor. Sedangkan untuk menjadi Perseroan Terbatas harus memenuhi ketentuan mengenai Modal Dasar Perseroan Terbatas, yakni minimal Rp. 50.000.000 (Berdasarkan Pasal 32 ayat (1) UUPT), dan $25 \%$ dari modal dasar harus ditempatkan dan disetor penuh (Berdasarkan Pasal 33 ayat (1) UUPT). Dengan demikian, Anggaran Dasar CV harus disesuaikan dengan ketentuan tersebut.

c. Membuat Akta pendirian (akta notaris) yang memuat Anggaran Dasar dan keterangan lain berkaitan dengan pendirian Perseroan Terbatas (Berdasarkan Pasal 7 ayat (1) jo. Pasal 8 ayat (1) UUPT).

22 NOTARIS SIDOARJO, Perubahan $\mathrm{CV}$ Menjadi PT, ..Loc.Cit 
d. Para pendiri bersama-sama mengajukan permohonan pengesahan badan hukum melalui jasa teknologi informasi sistem administrasi badan hukum secara elektronik kepada Menteri Hukum dan HAM (Berdasarkan Pasal 1 angka 16 jo. Pasal 9 ayat (1) UUPT.

e. Setelah dilakukan pengesahan, Menteri akan melakukan pendaftaran Perseroan Terbatas (Berdasarkan Pasal 29 ayat (1) UUPT).

f. Pengumuman di Tambahan Berita Negara RI oleh Menteri (Berdasarkan Pasal 30 ayat (1) UUPT).

Dan perubahan itu dapat dilakukan melalui cara berikut ini ${ }^{23}$ :

a. Seluruh sekutu harus setuju akan keinginan itu dan melakukan rapat dengan atau tanpa kehadiran notaris yang kemudian akan menghasilkan putusan perubahan itu dalam bentuk berita acara.

b. Seluruh aset bergerak maupun tidak bergerak Perseroan Komanditer (CV) harus di taksasi(penilaian dalam jumlah rupiah) sebaiknya dilakukan oleh independen auditor.

c. Dari total aset lalu ditentukan berapa besar bagian masing-masing dan apakah seluruhnya atau sebagian akan di inbreng (dimasukkan) ke dalam Perseroan Terbatas sebagai modal yang akan disetor oleh masing-masing pendiri Perseroan Terbatas (PT).

d. Datang ke Notaris untuk membuat Akta Pendirian Perseroan Terbatas (PT) dengan sudah menentukan nama, kedudukan, maksud dan tujuan, pemegang saham, susunan pengurus dan modal Perseroan Terbatas (PT).

e. Setelah proses pendirian Perseroan Terbatas (PT) tentu saja harus mengubah seluruh administrasi dan keuangan yang ada karena telah beralih status dari badan usaha menjadi badan hukum.

\footnotetext{
${ }^{23}$ Ibid
}

\section{Tanggung Jawab dari Sekutu Komplementer Terhadap Perseroan Terbatas (PT) Yang Didirikan}

Tanggung jawab, dalam istilah hukum berarti keterikatan atas konsenkuensi hukum dari setiap tindakan, kelalaian atau kecerobohan; dalam bahasa sederhana berarti bertanggung jawab atas tindakan seseorang atau kata-kata, membawa konsekuensi dari tindakan. ${ }^{24}$

Terdapatnya dua jenis sekutu dalam Persekutuan Komanditer, yaitu sekutu komplementer dan sekutu komanditer mengakibatkan terdapatnya dua jenis tanggung jawab pula, yaitu tanggung jawab tidak terbatas (unlimited liability) dan tanggung jawab terbatas (limited liability). Tanggung jawab tidak terbatas atau pribadi (personal liability) artinya bahwa kreditur dapat menuntut kewajiban persekutuan tidak saja dari aset persekutuan tetapi juga dari aset pribadi para sekutu. ${ }^{25}$

Ketentuan Pasal 20 KUHD mengatur mengenai tanggung jawab sekutu komanditer yang hanya bertanggung jawab sebesar modal yang disetorkan atau akan disetorkan ke dalam Persekutuan Komanditer, dengan syarat sekutu komanditer tersebut tidak ikut serta dalam pengurusan Persekutuan Komanditer dan keberadaannya tidak diketahui oleh pihak ketiga.

Pasal 20 KUHD secara eksplisit menyatakan larangan sekutu komanditer melakukan pengurusan terhadap Persekutuan Komanditer, meskipun berdasarkan surat kuasa tetapi tidak berarti bahwa sekutu komanditer tidak berperan sama sekali masuk ke dalam kepengurusan

24 Yetty Komalasari Dewi, Pemikiran Baru Tentang Commanditaire Venootschap (CV) Studi Perbandingan KUHD dan WvK Serta Pengadilan Indonesia dan Belanda. Badan Penerbit Fakultas Hukum Universitas Indonesia, Jakarta, 2011hlm. 182 25 Ibid 
Persekutuan Komanditer. $^{26}$ Sekutu komanditer boleh mengawasi pengurusan itu, dengan syarat ditetapkan demikian dalam akte pendirian. Pengawasan yang dilakukan oleh sekutu komanditer tersebut harus bersifat intern, berarti tindakan pengawasan tersebut tidak boleh menimbulkan kesan seolah-olah sekutu komanditer itu juga pengurus Persekutuan Komanditer.

Sekutu komplementer atau sekutu kerja merupakan sekutu yang menjadi pengurus persekutuan, sedangkan sekutu tidak kerja atau sekutu komanditer tidak mengurus persekutuan. Baik sekutu kerja maupun sekutu tidak kerja masing-masing memberikan pemasukannya, yang berwujud uang, barang atau tenaga (fisik atau pikiran) atas dasar pembiayaan bersama, artinya untung rugi dipikul bersama antara sekutu kerja dan sekutu komanditer, meskipun tanggung jawab sekutu komanditer terbatas pada modal yang disanggupkan untuk dimasukkan. Soekardono menamakan sekutu kerja itu sekutu komplementer, sedangkan sekutu yang tidak kerja disebut sekutu komanditer. ${ }^{27}$

Menurut Pasal 17 KUHD bila sekutu komplementer terdapat lebih dari satu orang harus ditegaskan diantara mereka, apakah diantara mereka ada yang dilarang untuk bertindak keluar. Meskipun telah ditegaskan di antara para sekutu komplementer mengenai siapa di antara mereka yang dilarang untuk bertindak keluar, tetapi hal tersebut tidak mengurangi tanggung jawab masing-masing dari sekutu komplementer untuk bertanggung jawab secara pribadi dan keseluruhan sampai harta pribadi secara tanggung menanggung. Dalam hal ini dikarenakan tidak semua sekutu dalam CV

26 M. Yaya Harahap, Hukum Perseroan Terbatas, Sinar Grafika, Jakarta, 2011,hlm. 18.

27 H.M.N. Purwosutjipto, Pengertian Pokok Hukum Dagang Indonesia dan Bentuk-Bentuk Perusahaan, Djambatan, Jakarta , 2010, hlm.74-75. bertindak keluar. Sehingga sekutu diam atau yang sering disebut dengan sleeping partner atau stille vennoot merupakan anggota persekutuan yang pasif dan tidak melakukan hubungan dengan pihak ketiga. ${ }^{28} \mathrm{Hal}$ ini disebabkan sekutu pasif atau sekutu komanditer hanya memiliki fungsi sebagai pelepas uang (geldschieter) atau pemberi uang, yaitu orang yang mempercayakan uangnya. Dalam hal ini CV memungkinkan pengumpulan modal yang lebih banyak dari sistem persekutuan firma.

Sekutu pengurus sering kali disebut sebagai komplementaris merupakan anggota yang aktif dengan tanggung jawabnya sampai kepada harta pribadinya. Sekutu komanditer tidak boleh mencampuri tugas sekutu komplementer atau sekutu pengurus. Namun, terkait dengan adanya hubungan dengan pihak ketiga, setiap sekutu komanditer yang ikut melakukan perbuatan pengurusan $\mathrm{CV}$ dan sekutu komanditer tersebut dengan mengizinkan pemakaian namanya dalam hal pengurusan $\mathrm{CV}$ maka akan memikul akibat hukum, yakni dianggap sukarela mengikatkan diri terhadap semua tindakan pengurus, oleh karenanya sekutu komanditer tersebut ikut bertanggung jawab secara solider atau bertanggung jawab secara keseluruhan atas utang Persekutuan Komanditer $^{29}$

Perjanjian-perjanjian atau perbuatan hukum yang dilakukan oleh para sekutu pada CV mengikat para sekutu Komplementer sehingga perikatan yang timbul adalah antara sekutu Komplementer dengan pihak ketiga menurut ketentuan Pasal 17 KUHD. Oleh karenanya perbuatan hukum yang dilakukan oleh sekutu aktif terhadap PT yang didirikan merupakan tanggung jawab seluruhnya sampai harta pribadi.

28 I.G. Rai Widjaya, Hukum Perusahaan, cet.

7, Kesaint Blanc ,Bekasi, 2007, hlm. 52

${ }^{29}$ M. Yahya Harahap, Op.Cit., hlm. 19 
Perjanjian-perjanjian atau perbuatan hukum apabila dilakukan oleh sekutu Komanditer, maka perbuatan hukum itu menjadi tanggung jawab dirinya seluruhnya sampai harta pribadi secara tanggung renteng dengan sekutu Komplementer dan pertanggungjawaban sekutu Komanditer tidak hanya terbatas pada uang yang dilepasnya pada CV sebagaimana ketentuan Pasal 21 KUHD.

Atas perbuatan hukum yang dilakukan oleh para sekutu tersebut apabila berkaitan dengan kepemilikan saham dan penyetorannya, maka Pasal 12 ayat (1) UUPT memberikan fasilitas agar perbuatan hukum tersebut tidak menjadi tanggung renteng pada para sekutu dan diambil alih oleh PT dengan beberapa pilihan, yaitu :

a. Bila perbuatan hukum tersebut dinyatakan dengan akta bukan otentik, akta tersebut dilekatkan pada anggaran dasar pendirian PT (Pasal 12 ayat (2) UUPT); dan

b. Bila perbuatan hukum tersebut dinyatakan dengan akta otentik, maka nomor, tanggal dan nama serta tempat kedudukan Notaris yang membuat akta otentik tersebut disebutkan dalam anggaran dasar pendirian PT (Pasal 12 ayat (3) UUPT).

Bilamana perbuatan hukum yang dilakukan sekutu Komplementer (dalam hal ini calon pendiri) yang berkaitan dengan kepemilikan saham, lalu tidak dicantumkan dalam anggaran dasar pendirian perseroan terbatas, maka akan menyebabkan tidak menimbulkan hak dan kewajiban serta tidak mengikat perseroan sebagaimana ketentuan Pasal 12 ayat (4) UUPT. Sehingga pertanggungjawaban Sekutu Komplementer tersebut secara pribadi sampai harta seluruhnya.

Bila perbuatan hukum yang dilakukan sekutu Komplementer (dalam hal ini sebagai calon pendiri perseroan) tersebut merupakan perbuatan hukum yang dilakukan untuk kepentingan perseroan sebelum didirikan, walaupun tidak dicantumkan dalam anggaran dasar pendirian perseroan tetap harus dituangkan dalam bentuk tertulis untuk selanjutnya harus dilakukan RUPS pertama kali sebagaimana penjelasan Pasal 13 ayat (1) UUPT paling lambat 60 (enam puluh) hari setelah perseroan memperoleh status badan hukum, dengan RUPS dihadiri oleh semua pemegang saham dengan hak suara dan keputusan disetujui dengan suara bulat. Hal tersebut semata-mata untuk mengikat perseroan sehingga menimbulkan pengalihan hak dan kewajiban atas segala perbuatan hukum yang dilakukan oleh sekutu komplementer kepada perseroan. Oleh karenanya bila tidak terpenuhi ketentuan-ketentuan tersebut maka calon pendiri atau eks sekutu Komplementer akan bertanggung jawab secara pribadi atas segala akibat yang timbul terhadap perbuatan hukum yang dilakukan tersebut.

Pada intinya setiap perbuatan hukum yang dilakukan oleh calon pendiri atau sekutu Komplementer dalam kondisi PT belum sah sebagai badan hukum, maka menjadi tanggung jawab pribadi orang yang melakukan perbuatan hukum tersebut karena tidak menimbulkan hak dan kewajiban serta tidak mengikat perseroan, sebagaimana ditegaskan dalam Pasal 3 ayat (2) huruf a UUPT.

\section{G. Kesimpulan}

1. Mekanisme dalam perubahan bentuk CV menjadi PT pada umumnya mengacu pada ketentuan yang mengatur tentang $\mathrm{CV}$ dan ketentuan yang mengatur tentang PT. Sebelum dilakukannya peningkatan atau perubahan bentuk CV menjadi PT, harus dilakukan pemberesan yang berupa penghitungan asset $\mathrm{CV}$ yang selanjutnya pada pendirian $\mathrm{PT}$, harta kekayaan $\mathrm{CV}$ tersebut dialihkan menjadi modal awal PT. Dengan peningkatan status yang 
dilakukan maka hukum CV yang dimaksud menjadi bubar, tidak diharuskan membuat Akta Pembubaran CV.

2. Pertanggunggjawaban sekutu aktif dalam $\mathrm{CV}$ yang mengalami perubahan bentuk dari CV menjadi PT terkait dengan perbuatan hukum yang telah dilakukan sebelumnya dengan Pihak Ketiga, apabila sekutu aktif yang melakukan perbuatan hukum sebagaimana dimaksud dalam Pasal 12 dan Pasal 13 UUPT dan telah memenuhi ketentuan dalam pasal-pasal tersebut, maka terjadi peralihan hak dan kewajiban dari sekutu aktif tersebut ke dalam perseroan dan perbuatan hukum yang dilakukan oleh sekutu aktif tersebut mengikat perseroan. Tetapi apabila ketentuan-ketentuan dalam Pasal 12 dan Pasal 13 UUPT tidak terpenuhi, maka sekutu aktif bertanggung jawab sampai harta pribadi, dan bertanggung jawab sampai harta pribadi secara tanggung renteng bersama-sama para sekutu dalam Persekutuan Komanditer.

\section{H. Saran}

1. Undang-undang Perseroan Terbatas kurang mencakup mengenai mekanisme peningkatan status CV menjadi PT. Demi menjamin kepastian hukum dari pendirian PT yang melanjutkan kegiatan usaha CV, melalui Sistem Administrasi Badan Hukum (SABH) diperlukan perbaikan-perbaikan aturan agar mempermudah penggunaan $\mathrm{SABH}$ dalam pelaksanaan prosedur dan mekanisme peningkatan status CV menjadi PT.

2. Untuk mencegah kemungkinan perbuatan hukum yang dilakukan sebelum pendirian perseroan tidak dicantumkan di anggaran dasar ataupun nantinya tidak disetujui oleh RUPS, maka sebaiknya para pengusaha melakukan perjanjian pendahuluan dengan para calon pendiri dan calon komisaris serta calon pemegang saham. Perjanjian ini setidaknya berisi kesepakatan yang kemudian dapat dikompromikan serta dapat menjadi jaminan dalam pembahasan anggaran dasar ataupun saat RUPS dilakukan.

\section{DAFTAR PUSTAKA}

\section{A. Buku :}

Abu Yasid, Aspek-aspek Penelitian Hukum; Hukum Islam - Hukum Barat, Pustaka Pelajar, Yogyakarta, 2010.

Bahder Johan Nasution, Metode Penelitian Ilmu Hukum, Mandar Maju, Bandung, 2008.

Bambang Waluyo, Penelitian Hukum Dalam Praktek, Sinar Grafika, Jakarta, 1996.

Bernard Arief Sidharta, "Penelitian Hukum Normatif: Analisis Penelitian Filosofikal dan Dogmatikal”, dalam
Sulistyowati Irianto dan Shidarta (Editor), Metode Penelitian Hukum Konstelasi dan Refleksi, Cetakan kedua, Yayasan Pustaka Obor Indonesia, Jakarta, 2011.

Binoto Nadapdap, Hukum Perseroan Terbatas, Permata Aksara, Jakarta, 2012.

H.M.N. Purwosutjipto, Pengertian Pokok Hukum Dagang Indonesia dan Bentuk-Bentuk Perusahaan, Djambatan, Jakarta , 2010.

Herlien Budiono, Ajaran Umum Hukum Perjanjian dan Penerpannya di 
Bidang Kenotariatan, PT. Citra Aditya Bakti, Bandung, 2009.

I.G. Rai Widjaya, Hukum Perusahaan, cet. 7, Kesaint Blanc ,Bekasi, 2007.

Johnny Ibrahim, Teori dan Metodologi Penelitian Hukum Normatif, Bayumedia Publishing, Cetakan Keempat, Malang, 2011.

Lihat juga Peter Mahmud Marzuki, 2010, Penelitian Hukum, Kencana, Jakarta.

M. Solly Lubis, Filsafat Ilmu dan Penelitian, CV. Mandar Maju, Bandung, 1994.

M. Yaya Harahap, Hukum Perseroan Terbatas, Sinar Grafika, Jakarta, 2011.

Ridwan Khairandy, Pokok-Pokok Hukum Dagang Indonesia, Pustaka Pelajar, Jakarta. 2013

Ronny Hanitijo Soemitro, Metodologi Penelitian Hukum dan Jurimetri, Semarang,Ghalia Indonesia, 1988.

Hukum dan Jurimetri,
Indonesia, Jakarta, 1990.

Satjipto Rahardjo, llmu Hukum, P.T. Citra Aditya Bakti, Bandung, 1991.

Publishing, Yogyakarta, 2010.

Soerjono Soekanto dan Sri Mamudji,
Op.Cit., hlm. 14.

Pengantar Penelitian Hukum Normatif, UI Press, Jakarta, 2006.

Yetty Komalasari Dewi, Pemikiran Baru Tentang Commanditaire Venootschap (CV) Studi Perbandingan KUHD dan WvK Serta Pengadilan Indonesia dan Belanda. Badan Penerbit Fakultas Hukum Universitas Indonesia, Jakarta, 2011.

Zainuddin Ali, Metode Penelitian Hukum, Sinar Grafika, Jakarta, 2009.

\section{B. Peraturan Perundang-undangan :}

Kitab Undang-undang Hukum Dagang, Staatsblad 1847-23

\section{Sumber Lain:}

Irma Devina, Peningkatan Bentuk Perusahaan Dari CV Menjadi PT, https:// irmadevita. com/2011/ peningkatan-bentuk-perusahaan-daricv-menjadi-pt/diakses tanggal $11 / 10 / 2018$

NOTARIS SIDOARJO, Perubahan CV Menjadi PT, http://notaris-sidoarjo. blogspot. com/2012/11/perubahan-cvmenjadi-pt_26.html diakses tanggal $19 / 09 / 2018$ 